\title{
THE ECONOMIC FACTORS AND CONSEQUENCES OF SOCIAL INEQUALITY AND POVERTY
}

\author{
Inessa SYTNIK ${ }^{1}$ \\ Opole University of Technology, Poland \\ Artem STOPOCHKIN ${ }^{2}$ \\ Wyższa Szkoła Biznesu - National-Louis University, Poland \\ Bogdan SYTNIK ${ }^{3}$ \\ Cracow University of Economics, Poland
}

\begin{abstract}
The purpose of the study is to determine the main factors and prerequisites for inequality and poverty of the population of Ukraine, as well as to identify the main consequences of this phenomenon and finding out of the main directions of the socio-economic policy of the state. Methodology. The article considers theoretical approaches to the definition of social inequality and poverty, as well as issues with fair distribution of national wealth. The results of the study confirmed the thesis of the authors that the problems of poverty and social inequality adversely affect the functioning of national socio-economic systems. It is proved that the most effective state is one which has a broad layer of the middle class, which ensures the rationalization of consumption, saving and investment processes. Practical significance. Based on official statistical data of the main macroeconomic indicators of the state development, this article studies main trends in the development of Ukrainian economy and its social component. The coefficients of the correlation dependence between the indicators of development of the social and economic systems of Ukraine are calculated and conclusions regarding the absence of a state system of equal distribution of national wealth are drawn. Value/originality. The result of the study is a statement about the need to modernize and reform the existing system of redistribution of national wealth in Ukraine with a view to reducing poverty and social inequality in the country.
\end{abstract}

Key words: poverty, social inequality, national wealth, distribution system, middle class.

JEL Classification: 132, D63, D31

\section{1. Вступиение}

В современных научных теориях выделяется Ава основных типа моделей развития рыночных экономик: миберальная (американская) и скоординированная (скандинавская). Амя миберамьной модеки развития рыночной экономки характерно минимальное вмешательство государства в процессы производства и перераспределения национального богатства и как результат более высокие темпы роста национальной экономики. В то время как скоорАинированная моАель рыночной экономики отличается активным вмешательством государства в хозяйственные процессы, большим объемом ВВП на Аушу населения, меньшим уровнем безработицы и более высоким уровнем социальной защищенности гражАан. Но, ни первая, ни вторая модемь не явмяется совершенной в пиане обеспечения высокого уровня жизни населения, полного решения проблем соци- ального неравенства и бедности. Более того, кризис мировой экономики и неравномерное распределение капитала внутри национацьных социацьно-экономических систем усугубляют проблему социального неравенства и бедности, как в высокоразвитых, так и в менее развитых странах мира.

В значительной степени эта проблема касается и Украины. Отсутствие жизнеспособной стратегии экономического развития и четкой внешней политики государства привели украинскую национальную социально-экономическую систему к структурным Аиспропорциям в реальном секторе экономики и глубокому финансовому кризису. Рост валового внутреннего продукта Украины во многом явмяется искусственным и не соответствует реальной ситуации в национальном хозяйстве. Прямым слеАствием чего становится массовое обнищание населения Украины, трудовая эмиграция и ухудшение Аемогра-

\footnotetext{
Corresponding author:

${ }^{1}$ Department of Organization and Management of Enterprise, Opole University of Technology.

E-mail: innasytnik@gmail.com

${ }^{2}$ Faculty of Social Sciences and Computer Science, Wyższa Szkoła Biznesu - National-Louis University.

E-mail: asfreedom1000@gmail.com

${ }^{3}$ Cracow University of Economics.

e-mail: bsytnik@outlook.com
} 
фической ситуации в стране (а в послеАнее время и военные Аействия на территории государства).

Обозначенные проблемы обуславливают актуальность Аанного исследования.

Целью исследования является определение главных факторов и предпосылок неравенства и бедности населения Украины, а также выявления основных послеАствий этого явления и на этой основе формирование основных направлений социально-экономической политики государства.

\section{2. Природа социального неравенства и беАности}

ПереА тем как говорить об экономических причинах социального расслоения населения и социально-экономических послеАствиях этого явления, следует Аать определения терминов «социальное неравенство» и «бедность», выяснить их природу и вАияние на развитие национальной экономики.

С экономической точки зрения «социальное неравенство» - это Аифференциация (разделение развивающегося целого) общества на отАельные социальные группы, в зависимости от профессионацьных, образовательных, имущественных и Аругих признаков. В результате этой Аифференциации отдельные члены общества имеют неравный доступ к ограниченным ресурсам и обладают неравными возможностями УАовметворения своих материальных и духовных потребностей (Gacalov, 2002: 306; Shkaratan, 2012: 40). Аифференциация общества явмяется естественным процессом развития социально-экономической системы государства. При этом уровень экономического неравенства колеблется с течением времени около оАной постоянной величины. САишком сильное усиление степени неравенства или равенства одинаково чревато национальной катастрофой и потрясениями. (Sorokin, 1992: 315-334).

В энциклопедических словарях понятие «беАность» связано с определением имущественного положения человека или групп населения с учетом минимахьного объема Аоходов. При этом в кажАой отАельной стране бедность характеризуется по-разному и имеет свои особенности в зависимости от принятой системы ценностей и общего уровня жизни населения. Черта бедности фиксируется на определенный отрезок времени. Различают Ава основных вида беАности: первичную или объективную бедность - жизнь ниже определенного уровня уАовлетворения основных потребностей человека; вторичную или субъективную бедность - жизнь с чувством субъективно воспринимаемого недостатка более высоких жизненных благ (Gacalov, 2002: 34).

В рамках концепции объективной беАности выдемяют Ава виАа беАности: абсолютную и относительную беАность. Абсолютная бедность определяется на основе сравнения Аушевых Аоходов населения и прожиточного минимума - бедный по доходам. Относительная бедность определяется на основе сравнения Аушевых Аоходов населения и выставменной (относительной) минией беАности - беАный по мишениям. В случае, когАа реальные Аоходы всего населения растут, а их распределение остается постоянным, показатель относительной беАности не изменяется. Таким образом, понятие относительной беАности явмяется составмяющей концепции социального неравенства (Batrakova, 2011: 117-121).

Аля кажАой конкретной национацьной социально-экономической системы характерна опреАеленная специфика финансово-экономических и социальных отношений. Эта специфика во многом определяет участие населения в процессе перераспределения национального богатства.

Еще Аревнегреческие ученые задавались вопросами о бедности и справеАливом распределении национального богатства. Так Пцатон в своей работе «Государство» писал: «... при росте и благоустройстве нашего государства наАо преАоставить всем сословиям возможность иметь свою Аолю в общем процветании, соответственно их природным Аанным» (Platon, 2015). При этом он говорих о необходимости устранения богатства и беАности, так как «... ОАно веАет к роскоши, мени, новшествам, Аругая кроме новшеств - к низостям и злодеяниям» (Platon, 2015). Тем самым Пиатон утвержАац, что идеальное госуАарство Аолжно стремиться к постоянному развитию на основе обеспечения социальной справеАмивости и равенства своих граждан.

Ученик Пиатона Аристотель в труде «Политика» развии идею необходимости социального равенства.

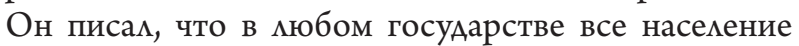
можно разделить на три класса: класс очень богатых,

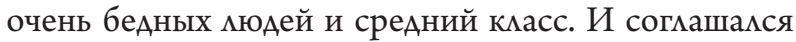
с Пиатоном относительно вредности Аля развития государства как очень богатого, так и очень беАного населения. Аристотель утвержАац, что из бедных получаются преступники, из богатых - мошенники, а наилучшим является средний класс. Согласно Аристотелю, государство, «...гАе среАний слой гражАан количественно превосходит богачей и беАняков, вместе взятых, или, но крайней мере, один из этих слоев» явмяется наиболее жизнеспособным, так как именно его представители в соответствии со сложившимися экономическими реалиям наиболее готовы следовать рациональному принципу и тем самым стимулировать устойчивое развитие всей государственной системы (Dovatur, 1983: 38-52).

Исследования современных ученых-экономистов таких как Кудуэль А., Хендшель Й., Уодон К. (Kudujel', 2002), Аевис О., Ферман А., Корнблун И., Хабер А. (Lewis, 1965), Аекарь С., Привалов Ю., Шабанов В. (Lekar', 2011), Аощинин M. (Loshhinin, 2010), Росс А., Скотт К., Смит П. (Ross, 2000), ТаунсенА П. (Townsend, 1979), Шевяков А., Кирута А. (Shevjakov, 
2009), Хавриш $\Lambda$. (Hawrysz, 2016) и Аругих, также подтвержАают тезис о том, что проблемы бедности и социального неравенства населения отрицательно сказываются на процессе функционирования национальных социально-экономических систем, а наиболее эффективным государством явмяется такое, в котором имеется широкий слой среАнего класса, который и обеспечивает рационализацию процессов потребления, сбережения и инвестирования.

\section{3. Экономический рост, социамьное неравенство и беаность в Украине}

Уровень беАности в государстве во многом опреАеляется величиной получаемого дохода и уровнем потребления населения, что в свою очереАь напрямую зависит от объемов ВВП и темпов экономического роста. Кроме того изменение объемов и темпов роста ВВП может вмиять на изменения в распределении Аохода среАи населения, то есть социальное неравенство. Поэтому Аахее проведем анализ Аинамики ВВП Украины за 2000-2015 гг. Резумьтаты этого анализа можно использовать Аля моделирования размичных вариантов экономической политики государства, направленной на совершенствование системы распределения национального богатства, нивелирования социального неравенства и снижение уровня беАности населения.

Анализируя базовые темпы прироста реального валового внутреннего продукта (табц. 1), можно сделать следующие выводы. За период с 2000 г. по 2015 г. объем реального ВВП Украины сократился на 22,4\%. При этом, с 2000 по 2007 гг. в Украине наблюАался экономический рост, реальный ВВП за этот период увеличился на 40,6\%. ОАнако уже в 2005 г. были заложены отрицательные тенденции развития национальной экономки (реальный ВВП в 2005 г. уменьшился по отношению к 2004 г. на 2,9\%), затем
2006-2007 гг. - это период стабилизации и экономического роста (хотя в 2007 г. темпы прироста ВВП были в 2 раза ниже, чем в 2006 г. - 2,6\% по сравнению с 5,1\%). С 2008 г. экономика Украины вошиа в «штопор» экономического кризиса, в результате чего реальный ВВП за период 2008-2015 гг. обвалился на $44,8 \%$.

Следующим важным индикатором развития национальной социально-экономической системы и соответственно уровня беАности и социального неравенства в стране явцяется физический объем ВВП (табл. 2). Анализ этого показатемя свидетельствует о приросте физического объема ВВП Украины с 2000 по 2010 гг. В 2012-2013 гг. наблюдается нулевой прирост показатемя, а в 2014-2015 гг. - снижение физического объема ВВП Украины. В 2015 г. произошио значительное снижение объемов ВВП Украины - ВВП 2015 г. на 3,44\% меньше ВВП 2004 г., а это значит, что по объемам произведенной проАукции и услуг на начало 2016 г. экономика страны была отброшена на 12 мет назаА. При этом наблюАается низкий уровень зависимости межАу темпами прироста реального валового внутреннего продукта в Аенежном эквиваленте и физическом объеме ВВП (см. табл. 1 и 2). Так в Аенежном эквиваленте ВВП Украины начал снижаться уже в 2008 г., в то время как физический объем ВВП возрастал впиоть до 2012 г. В Аенежном эквиваленте ВВП Украины в 2015 г. уменьшился по сравнению с 2000 г. на $22,4 \%$, а в физическом объеме вырос на $35,42 \%$. Такая ситуация может свидетельствовать с оАной стороны о низкой конкурентоспособности национацьного производителя (за большее количество произвеАенной продукции получаем меньший АохоА), а с Аругой стороны о высоком уровне инфмяции (реальный АохоА значительно ниже номинацьного - инфмяции «съеАает» часть Аохода, полученного товаропроизводителями) и неразумной валютно-курсовой политики госу-

Таблица 1

Реальые цепные и базисные темпы прироста ВВП Украины с учетом Аефмятора ВВП

\begin{tabular}{|c|c|c|c|c|c|c|c|c|c|c|c|c|c|c|c|c|}
\hline Го $\mathrm{A}$ & 2000 & 2001 & 2002 & 2003 & 2004 & 2005 & 2006 & 2007 & 2008 & 2009 & 2010 & 2011 & 2012 & 2013 & 2014 & 2015 \\
\hline 2000 & 0,0 & & & & & & & & & & & & & & & \\
\hline 2001 & 7,7 & 0,0 & & & & & & & & & & & & & \\
\hline 2002 & 13,0 & 5,0 & 0,0 & & & & & & & & & & & & \\
\hline 2003 & 22,9 & 14,2 & 8,7 & 0,0 & & & & & & & & & & & \\
\hline 2004 & 34,2 & 24,7 & 18,7 & 9,2 & 0,0 & & & & & & & & & & & \\
\hline 2005 & 30,3 & 21,0 & 15,3 & 6,0 & $-2,9$ & 0,0 & & & & & & & & & \\
\hline 2006 & 37,0 & 27,3 & 21,2 & 11,5 & 2,1 & 5,1 & 0,0 & & & & & & & & \\
\hline 2007 & 40,6 & 30,6 & 24,4 & 14,4 & 4,8 & 7,9 & 2,6 & 0,0 & & & & & & & \\
\hline 2008 & 31,7 & 22,3 & 16,5 & 7,1 & $-1,9$ & 1,1 & $-3,9$ & $-6,3$ & 0,0 & & & & & & \\
\hline 2009 & 10,0 & 2,2 & $-2,7$ & $-10,5$ & $-18,0$ & $-15,6$ & $-19,7$ & $-21,8$ & $-16,5$ & 0,0 & & & & & \\
\hline 2010 & 8,2 & 0,5 & $-4,3$ & $-12,0$ & $-19,4$ & $-17,0$ & $-21,0$ & $-23,0$ & $-17,8$ & $-1,6$ & 0,0 & & & & \\
\hline 2011 & 11,8 & 3,9 & $-1,1$ & $-9,0$ & $-16,7$ & $-14,2$ & $-18,4$ & $-20,5$ & $-15,1$ & 1,6 & 3,3 & 0,0 & & & & \\
\hline 2012 & 11,4 & 3,5 & $-1,5$ & $-9,4$ & $-17,0$ & $-14,5$ & $-18,7$ & $-20,8$ & $-15,4$ & 1,3 & 3,0 & $-0,4$ & 0,0 & & & \\
\hline 2013 & 11,2 & 3,3 & $-1,6$ & $-9,5$ & $-17,2$ & $-14,7$ & $-18,8$ & $-20,9$ & $-15,6$ & 1,1 & 2,8 & $-0,6$ & $-0,2$ & 0,0 & & \\
\hline 2014 & 1,3 & $-5,9$ & $-10,4$ & $-17,6$ & $-24,5$ & $-22,3$ & $-26,1$ & $-28,0$ & $-23,1$ & $-7,9$ & $-6,4$ & $-9,4$ & $-9,1$ & $-8,9$ & 0,0 & \\
\hline 2015 & $-22,4$ & $-28,0$ & $-31,4$ & $-36,9$ & $-42,2$ & $-40,5$ & $-43,4$ & $-44,8$ & $-41,1$ & $-29,5$ & $-28,3$ & $-30,6$ & $-30,4$ & $-30,3$ & $-23,4$ & 0,0 \\
\hline
\end{tabular}

Источник: рассчитано автором на основе данных (Gosudarstvennaja sluzhba statistiki Ukrainy, 2017) 
Аарства. Все это факторы, приводящие к снижению уровня реального дохода населения, увеличению бедности и социального неравенства в стране.

Аамее рассмотрим Аинамику физического объема ВВП Украины на Аушу населения за 2000-2015 гг. и сравним ее с Авумя предыдущими показателями (рис. 1). Следует подчеркнуть, что именно ВВП на Аушу населения более тесно отражает зависимость межАу уровнем благосостояния населения и ростом национацьной экономики.

По результатам проведенного анализа можно сАелать вывоА, что физический объем ВВП на Аушу населения в Украине растет на протяжении всего анализируемого периода (2000-2015 гг.). Наибольшие темпы его прироста приходятся на 2007-2008 гг.
(78,1 и 83,0\% к 2000 г. соответственно), с 2009 г. происходит некоторое снижение этого показателя. Тем не менее, физический объем ВВП на Аушу населения в 2015 г. увеличился на 47,5\% по сравнению с 2000 г. Анализируя статистические Аанные, преАставленные на рисунке 1, следует отметить, что прирост физического объема ВВП на Аушу населения происходит более интенсивно, чем прирост общей величины ВВП (как в физическом, так и в Аенежном выражении). Такая ситуация подтвержАает предыдущие выводы о снижении реальных Аоходов населения и росте беАности в стране, слеАствием чего становится уменьшении численности населения (отток рабочей силы за границу, ухудшение общей демографической ситуации в стране).

Таблица 2

Цепные и базисные темпы прироста физического объема ВВП Украины

\begin{tabular}{|c|c|c|c|c|c|c|c|c|c|c|c|c|c|c|c|c|}
\hline & 2000 & 2001 & 2002 & 2003 & 2004 & 2005 & 2006 & 2007 & 2008 & 2009 & 2010 & 2011 & 2012 & 2013 & 2014 & 2015 \\
\hline 2000 & 0 & & & & & & & & & & & & & & & \\
\hline 2001 & 8,8 & 0 & & & & & & & & & & & & & \\
\hline 2002 & 14,57 & 5,3 & 0 & & & & & & & & & & & & \\
\hline 2003 & 25,45 & 15,3 & 9,5 & 0 & & & & & & & & & & & & \\
\hline 2004 & 40,25 & 28,91 & 22,42 & 11,8 & 0 & & & & & & & & & & & \\
\hline 2005 & 44,6 & 32,91 & 26,22 & 15,27 & 3,1 & 0 & & & & & & & & & & \\
\hline 2006 & 55,59 & 43,01 & 35,81 & 24,03 & 10,94 & 7,6 & 0 & & & & & & & & \\
\hline 2007 & 68,35 & 54,73 & 46,94 & 34,2 & 20,03 & 16,42 & 8,2 & 0 & & & & & & & & \\
\hline 2008 & 72,05 & 58,14 & 50,18 & 37,15 & 22,67 & 18,98 & 10,58 & 2,2 & 0 & & & & & & & \\
\hline 2009 & 46,07 & 34,26 & 27,5 & 16,44 & 4,149 & 1,018 & $-6,12$ & $-13,2$ & $-15,1$ & 0 & & & & & & \\
\hline 2010 & 52,06 & 39,76 & 32,73 & 21,21 & 8,42 & 5,16 & $-2,27$ & $-9,67$ & $-11,6$ & 4,1 & 0 & & & & & \\
\hline 2011 & 60,43 & 47,45 & 40,03 & 27,88 & 14,38 & 10,94 & 3,107 & $-4,71$ & $-6,76$ & 9,825 & 5,5 & 0 & & & & \\
\hline 2012 & 60,75 & 47,74 & 40,31 & 28,14 & 14,61 & 11,17 & 3,313 & $-4,52$ & $-6,57$ & 10,05 & 5,711 & 0,2 & 0 & & & \\
\hline 2013 & 60,75 & 47,74 & 40,31 & 28,14 & 14,61 & 11,17 & 3,313 & $-4,52$ & $-6,57$ & 10,05 & 5,711 & 0,2 & 0 & 0 & & \\
\hline 2014 & 50,14 & 37,99 & 31,05 & 19,68 & 7,047 & 3,828 & $-3,51$ & $-10,8$ & $-12,7$ & 2,782 & $-1,27$ & $-6,41$ & $-6,6$ & $-6,6$ & 0 & \\
\hline 2015 & 35,42 & 24,47 & 18,21 & 7,95 & $-3,44$ & $-6,35$ & -13 & $-19,6$ & $-21,3$ & $-7,29$ & $-10,9$ & $-15,6$ & $-15,8$ & $-15,8$ & $-9,8$ & 0 \\
\hline
\end{tabular}

Источник: рассчитано автором на основе данных (Gosudarstvennaja sluzhba statistiki Ukrainy, 2017)

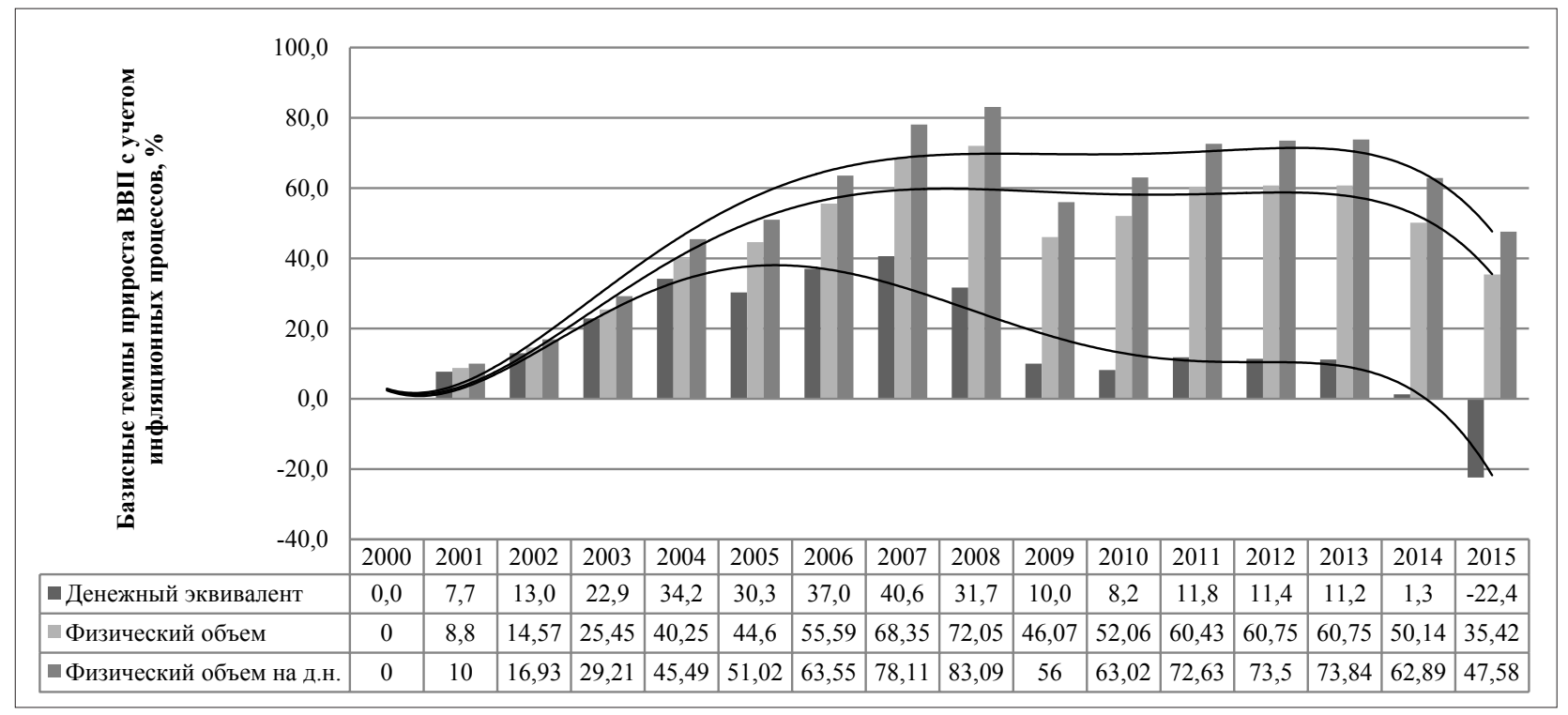

Рис. 1. Сравнительный анализ базисных темпов прироста ВВП Украины в Аенежном эквиваленте, физическом объеме и физическом объеме на Аушу насемения за 2000-2015 гг., в \%

Источник: рассчитано автором на основе данных (Gosudarstvennaja sluzhba statistiki Ukrainy, 2017) 
Аалее на основе использования корреляционно-регрессионного анализа выявим зависимости межАу базисными темпами прироста основных показателей развития социально-экономической системы Украины за период 2000-2015 гг. (табц. 3).

Проведенные расчеты подтвержАают преАыАущие выводы о низкой Зависимости меЖАУ объемом реального ВВП в Аенежном эквиваленте и физическим объемом общего ВВП на Аушу населения (коэффициенты корреляции составмяют 0,40 и 0,31). Кроме того низкая корреляция реального ВВП в Аенежном эквиваленте наблюдается и со всеми Аругими анализируемыми показателями, преАставленными в таблице 3, кроме уровня занятого населения. А это значит, что экономика накачивается «пустыми» эмиссионными Аеньгами, которые реацьно не способствуют ее развитию и повышению уровня благосостояния и социальной защищенности населения. Наблюдается ситуация, когАа на фоне роста ВВП в Аенежном эквиваленте население становится более беАным и социальное неравенство увеличивается.

Следующие Ава показателя - физический объем ВВП всего и на Аушу насемения. Эти показатели имеют тесную корремяционную зависимость как межАу собой, так в равной степени с такими показатемями, как минимальная и реацьная заработная плата, фонА заработной платы. С остальными показатемями зависимость низкая. Такая ситуация свидетельствует о том, что увемичение физического объема ВВП Украины влияет только на повышение заработной платы, но при этом никак не способствует снижению уровня безработицы и соответственно повышению уровня занятого населения, улучшению Аемографической ситуации в стране, обновлению основных фондов (что является оАним из определяющих факторов обеспечения экономического роста и устойчивого развития мюбой национальной соци- ально-экономической системы). Таким образом, можем сАелать вывоА о том, что экономика Украины на протяжении анализируемого периода (20002015 гг.) функционирует в режиме «проедания» собственных ресурсов. А, как известно, обязательным условием существования какой-либо системы явмяется инвестирование в ее развитие. Отсутствие такого инвестирования приводит сначала к застою, а потом к Аеформациям и полному разрушению всей системы.

Уровень беАности и социального неравенства в государстве во многом определяется состоянием рынка труда. Аля анализа рынка труда в Украине используем базисные темпы прироста численности населения, занятого насемения и штатных сотрудников за период 2001-2015 гг. к 2000 г. (рис. 2).

Анализируя данные, представленные на рисунке 2, можно выАелить слеАующие тенденции развития рынка труда в Украине в 2000-2015 гг. Начиная с 2002 г. и до 2008 г. включительно в Украине наблюАамась тенденция к незначительному возрастанию численности населения. В итоге численность населения в стране в 2008 г. была на 3,95\% больше, чем в 2000 г. ОАнако начиная с 2009 г. численность населения Украины неукмонно снижалась и к 2015 г. была на 15\% меньше, чем в 2000 г. Если сравнить эти Аанные с Аанными, представленными на рисунке 1 , то можно заметить, что тенденция снижения численности населения в основном совпадает с тенденцией прироста уровня ВВП. То есть можем утвержАать, что наблюдается прямая зависимость межАу темпами экономического роста в стране и численностью насемения (чем больше проблем в экономке страны, тем больше отток мюАских ресурсов).

Анализируя Аанные относительно занятого насемения и количества штатных сотруАников, можем выделить тенденцию постоянного снижения этих

Таблица 3

Коэффициенты коррекяционной зависимости межАу базисными темпами прироста основных показатемей развития социально-экономической системы Украины (исследуемый период 2000-2015 гг.)

\begin{tabular}{|c|c|c|c|c|c|c|c|c|c|c|c|c|}
\hline № & Наименование показатемя & 1 & 2 & 3 & 4 & 5 & 6 & 7 & 8 & 9 & 10 & 11 \\
\hline 1 & ВВП в денежном эквиваленте & 1,00 & & & & & & & & & & \\
\hline 2 & Физический объем ВВП & 0,40 & 1,00 & & & & & & & & & \\
\hline 3 & $\begin{array}{l}\text { Физ. объем ВВП на Аушу } \\
\text { населения }\end{array}$ & 0,31 & 1,00 & 1,00 & & & & & & & & \\
\hline 4 & $\begin{array}{l}\text { Степень износа основных } \\
\text { фондов }\end{array}$ & 0,31 & $-0,62$ & $-0,68$ & 1,00 & & & & & & & \\
\hline 5 & Насемение всего & 0,65 & $-0,31$ & $-0,39$ & 0,69 & 1,00 & & & & & & \\
\hline 6 & Уровень занятого населения & 0,86 & 0,02 & $-0,07$ & 0,56 & 0,93 & 1,00 & & & & & \\
\hline 7 & Уровень безработицы & $-0,38$ & $-0,93$ & $-0,92$ & 0,48 & 0,40 & 0,04 & 1,00 & & & & \\
\hline 8 & $\begin{array}{l}\text { СреАнее кол-во штатных } \\
\text { сотрудников }\end{array}$ & 0,41 & $-0,56$ & $-0,63$ & 0,76 & 0,92 & 0,77 & 0,61 & 1,00 & & & \\
\hline 9 & Минимальная зарплата & 0,04 & 0,78 & 0,81 & $-0,89$ & $-0,48$ & $-0,26$ & $-0,67$ & $-0,63$ & 1,00 & & \\
\hline 10 & Реальная средняя зарпиата & 0,07 & 0,88 & 0,91 & $-0,86$ & $-0,50$ & $-0,25$ & $-0,78$ & $-0,69$ & 0,97 & 1,00 & \\
\hline 11 & ФонА заработной платы* & 0,20 & 0,91 & 0,93 & $-0,80$ & $-0,39$ & $-0,11$ & $-0,81$ & $-0,60$ & 0,95 & 0,99 & 1,00 \\
\hline
\end{tabular}

*Количество занятого населения, умноженное на среАний уровень заработной пиаты по периодам

Источник: рассчитано автором на основе данных (Gosudarstvennaja sluzhba statistiki Ukrainy, 2017) 
показателей на протяжении всего анализируемого периода. Так в 2015 г. занятое население уменьшимось на 17,75\% по сравнению с 2000 г., а численность штатных сотрудников на 41,04\%. При этом, тенденция на резкое снижение этих показателей наблюдается именно с 2009 г. - года новой волны экономического кризиса в Украине. Также следует отметить, что количество штатных сотрудников снижается гораздо более высокими темпами, чем общая численность занятого населения. А это значит, что с кажАым годом все больший процент от занятого населения Украины теряет гарантию таких элементарных составцяющих социацьной защищенности, как постоянное рабочее место (и соответственно стабильный АохоА), оплачиваемый отпуск.
Важнейшим индикатором, характеризующим долю каждого конкретного человека в системе перераспреАеления национального богатства, явмяется зарпиата. Именно заработная пиата явмяется главным фактором, определяющим уровень социального неравенства и бедности в государстве. Потому далее проанамизируем отклонение уровня минимальной и среАней заработной платы от прожиточного минимума в Украине за период 2000-2015 гг. (рис. 3). По этим показателям ситуация в Украине выглядит несколько кучше, чем по всем преАыдущим. Ао 2009 г. включительно минимальная заработная пиата была ниже официально зарегистрированного прожиточного минимума, а начиная с 2010 г. эти Ава показателя соответствуют Аруг Аругу. СреАняя зарплата была ниже

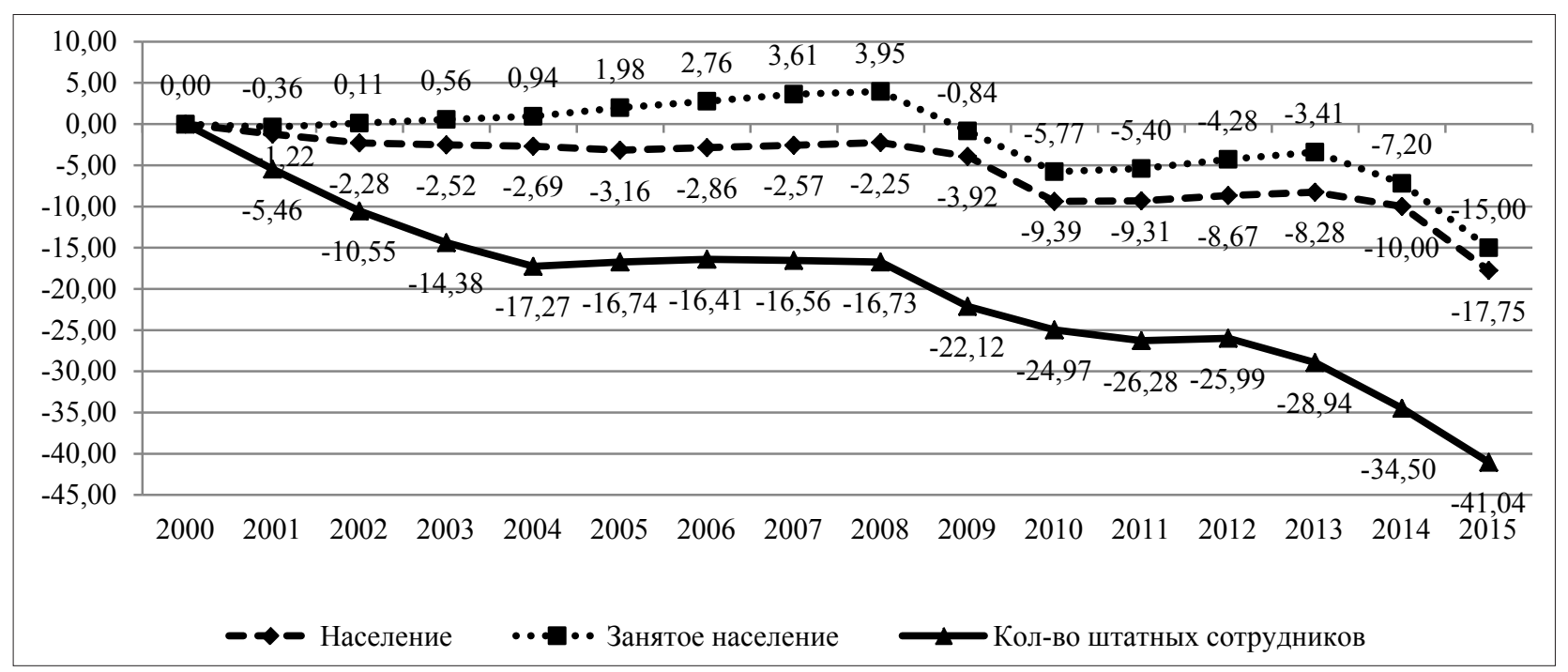

Рис. 2. Темпы прироста численности населения, занятого населения и количества штатных сотруАников в Украине в 2001-2015 гг., \% к 2000 г.

Источник: рассчитано автором на основе данных (Gosudarstvennaja sluzhba statistiki Ukrainy, 2017)

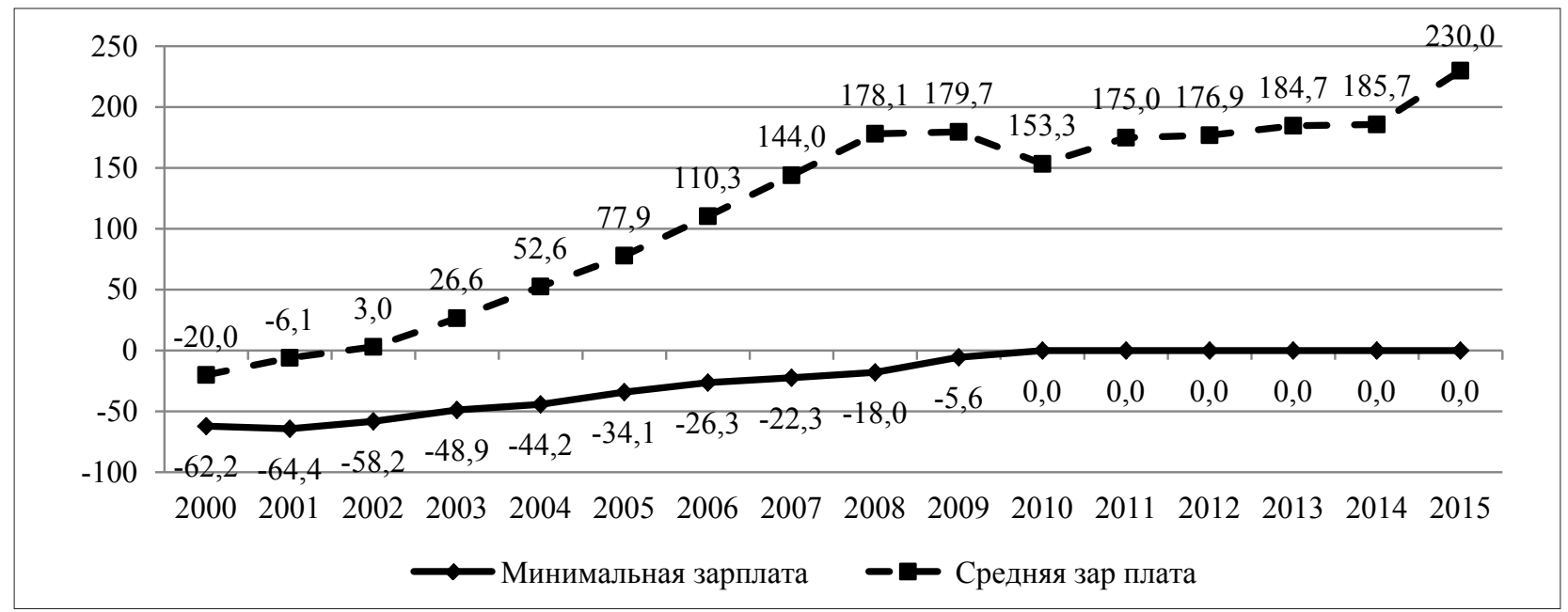

Рис. 3. Процентное откАонение уровня минимамьной и среАней заработной пхаты от прожиточного минимума в Украине* *Нулевой уровень - прожиточный минимум в соответствующем периоде

Источник: рассчитано автором на основе данных (Gosudarstvennaja sluzhba statistiki Ukrainy, 2017) 
прожиточного минимума только Ао 2001 г. вкАючительно, а начиная с 2002 г. она превышает этот показатель. Причем разница межАу официально зарегистрированным прожиточным минимумом и средней зарплатой постоянно возрастает и в 2015 г. превышение составцяет 230\%. То есть в первом приближении согласно данным показателям уровень жизни среднестатистического украинца Аолжен расти.

ОАнако нельзя Аелать выводы только по одной группе показателей, необходимо компиексно посмотреть на все составмяющие, характеризующие уровень развития национальной социально-экономической системы. И зАесь мы можем заметить, что увеличение разрыва межАу средней зарплатой и прожиточным минимумом в пользу первого показателя иАет на фоне падения объема ВВП, неэффективной системы инвестирования в национальное хозяйство, высокого уровня инфмяции (цены на потребительские товары в Украине в 2014 г. увеличились на 24,9\%, в 2015 г. - на 43,3\%), снижения уровня занятого насемения и численности штатных сотруАников, снижения общей численности населения страны. А это означает, что НСЭС работает не Аостаточно эффективно, чтобы произошио реальное повышение уровня жизни населения. ПодтвержАением этого тезиса также явцяются статистические Аанные, свидетельствующие о том, что в 2014 г. реальный доход населения Украины снизился на $11,5 \%$ и составил 88,5\% от дохода 2013 г., а в 2015 г. 77,7\% от дохода 2014 г. (Gosudarstvennaja sluzhba statistiki Ukrainy, 2017). Прямым слеАствием снижения реальных доходов населения является увемичение уровня социального неравенства, что в свою очередь явмяется фактором Аальнейшей дестабилизации всей национальной социально-экономической системы. Таким образом, круг замыкается - государство остается бедным, потому что бедно изначально. Более того маховик кризисных явлений в экономике может раскручиваться поА влиянием внешних дестабилизирующих факторов.

\section{4. Закиючение}

Проведенные исследования позволяют сделать слеАующие выводы.
1. Уровень жизни населения явмяется одним из определяющих факторов устойчивого развития национальных социально-экономических систем. Это определяется тем, что пиатежеспособный спрос населения обеспечивает инвестирование процесса расширенного воспроизводства. В связи с этим экономическая политика государства Аолжна быть направлена на снижение уровня бедности и социамьного неравенства в стране.

2. ОАним из опреАемяющих факторов беАности и социального неравенства явмяется система распреАеления национального богатства в государстве. При этом существует четкая зависимость: чем выше уровень развития государства, тем совершеннее система распределения национального богатства и тем выше уровень благосостояния граждан.

3. Наличие процессов роста в национальной экономике является неотъемлемым условием высокого уровня благосостояния населения и его социальной защищенности. Соответственно, увеличение беАности и социального неравенства явцяется прямым слеАствием развития кризисных явлений в национальной социально-экономической системе.

4. Результаты проведенного анализа основных индикаторов социально-экономического развития в Украине за 2000-2015 гг. свидетельствуют о том, что начиная с 2008 г. экономика Украины вошла в «штопор» экономического кризиса, в результате чего произошло падение реальных доходов насемения, рост беАности и социацьного неравенства в госуаарстве.

5. Амя снижения уровня беАности и социального неравенства в стране экономическая политика госуАарства Аолжна быть направлена на Аостижение полной занятости и высоких доходов населения на основе реструктуризации системы национацьного хозяйства. СозАание новых рабочих мест, инвестирование в человеческий капитац на основе совершенствования системы перераспределения национального богатства Аолжно стать приоритетом номер оАин Аля национацьного правительства. В противном случае Украине в ближайшей перспективе грозит полный экономический и социацьный комлапс.

\section{References:}

Batrakova L. G., (2011). Osnovnye koncepcii ocenki bednosti naselenija. - Jaroslavskij pedagogicheskij vestnik, (3/2011) Tom I (Gumanitarnye nauki): 117-121 s.

Detskaja bednost' v razvivajushhihsja stranah. - Bristol': Policy Press 2003

Dovatur A.I., (1983). «Politika» Aristotelja: T. 4. - Moskva: Mysl', 38-52 s.

Gacalov M., (2002). Sovremennyj jekonomicheskij slovar'-spravochnik. - Uhta: UGTU, 371 s.

Gosudarstvennaja sluzhba statistiki Ukrainy (2017). Elektronnyj resurs, Rezhym dostupu: www.ukrstat.gov.ua.

Hawrysz L., (2016). Social aspects of CSR reporting in Polish banks listed on the Warsaw stock exchange, SOCIALSGEM, 3th International Multidisciplinary Scientific Conferences SGEM2016, Social Sciences\&Arts Conference Procedings, Bulgaria 2016, p. 587-594Kudujel' A., Hendshel' J., Uodon K. (2002). Izmerenie i analiz bednosti. Elektronnyj resurs, Rezhym dostupu: http://siteresources.worldbank.org/INTPRS1/Resour ces/383606-1205334112622/4768783-1205337114531/11026_data_ru.pdf. 
Lewis O., (1965). The culture of poverty / Poverty in America. - University of Michigan press, $215 \mathrm{s.}$

Loshhinin M.B., (2010). Ocenka neravenstva uchastnikov rynochnogo sociuma Ukrainy. - Sankt-Peterburgskij nauchnyj forum «Nauka i obshhestvo»: Jekonomika i sociologija HHI veka: Tezisy dokladov. - Sankt-Peterburg: Cifrovoj tipografskij centr Izdatel'stva Politehnicheskogo universiteta, 328 - $342 \mathrm{~s}$.

Lekar' S., Privalov Ju., Shabanov V., Loshhinin M., (2011). Neodnorodnost' poselenchestva: social'nojekonomicheskij aspect. - Ekonomist, (6/2011), 4-30 s.

Platon (2015). Gosudarstvo. Kniga chetvertaja. Model' ideal'nogo gosudarstva (utopija) / Perevod s drevnegrech. A.N. Egunova. - Moskva: Akademicheskij proekt, 398 s. Elektronnyj resurs, Rezhym dostupu: http://www.e-reading. club/chapter.php/45069/19/Platon_-_Gosudarstvo.html

Platon (2015). Gosudarstvo. Kniga chetvertaja. Ustranenie bogatstva i bednosti v ideal'nom gosudarstve / Perevod s drevnegrech. A.N. Egunova. - Moskva: Akademicheskij proekt, 398 s. Elektronnyj resurs, Rezhym dostupu: http://www.e-reading.club/chapter.php/45069/20/Platon_-_Gosudarstvo.html

Ross D., Scott K., Smith P., (2000). The Canadian Fact Book on Poverty. - Ottawa: Canadian Council on. Social Development.

Sorokin P.A., (1992). Chelovek. Civilizacija. Obshhestvo / Obshh. red., sost. i predisl. A. Ju. Sogomonov: Per. s angl. - Moskva: Politizdat, $543 \mathrm{~s}$.

Shevjakov A.Ju., Kiruta A.Ja., (2009). Neravenstvo, jekonomicheskij rost i demografija: neissledovannye vzaimosvjazi. - Uchrezhdenie Rossijskoj akad. nauk In-t soc.-jekonom. problem narodonaselenija RAN. - Moskva: M-Studio, $192 \mathrm{~s}$.

Shkaratan O.I., (2012). Sociologija neravenstva. Teorija i real'nost'. - Moskva: Izdatel'skij dom Vysshej shkoly jekonomiki, $526 \mathrm{~s}$.

Townsend Peter Brereton, (1979). Poverty in the United Kingdom: a survey of household resources and standards of living. - Harmondsworth: Penguin Books, 1214 p.

\section{Инесса СЫТНИК, Артем СТЕПОЧКИН, Богдан СЫТНИК \\ ЭКОНОМИЧЕСКИЕ ФАКТОРЫ И ПОСЛЕДСТВИЯ СОЦИАЛЬНОГО НЕРАВЕНСТВА И БЕДНОСТИ В УКРАИНЕ}

Аннотация. Целью исследования является определение главных факторов и предпосылок неравенства и бедности населения Украины, а также выявления основных последствий этого явления и на этой основе формирование основных направлений социально-экономической политики государства. Методология. В статье рассмотрены теоретические подходы к определению социального неравенства и бедности, а также вопросы справедливого распределения национального богатства. Результаты исследования позволили подтвердить тезис авторов о том, что проблемы бедности и социального неравенства отрицательно сказываются на процессе функционирования национальных социально-экономических систем. Доказано, что наиболее эффективным государством является такое, в котором имеется широкий слой среднего класса, который и обеспечивает рационализацию процессов потребления, сбережения и инвестирования. Практическое значение. На основе официальных статистических данных основных макроэкономических показателей развития государства в статье исследованы тенденции развития экономики Украины и ее социальной составляющей. Рассчитаны коэффициенты корреляционной зависимости между показателями развития социально-экономической системы Украины и сделаны выводы об отсутствии в стране системы справедливого распределения национального богатства. Значение/оригинальность. Результатом проведенного исследования является вывод о необходимости модернизации и реформирования имеющийся системы перераспределения национального богатства в Украине с целью снижения бедности и социального неравенства в стране. 